\title{
The Recovery Umbrella in the World of Elite Sport: Do Not Forget the Coaching and Performance Staff
}

\author{
Julio Calleja-González ${ }^{1,2, *(\mathbb{D})}$, Stephen P. Bird ${ }^{3,4} \mathbb{D}$, Thomas Huyghe ${ }^{5} \mathbb{(}$, Igor Jukic ${ }^{6}$, Francesco Cuzzolin ${ }^{7}$, \\ Francesc $\operatorname{Cos}^{8}$, Diego Marqués-Jiménez ${ }^{9}$, Luka Milanovic ${ }^{10}$, Jaime Sampaio ${ }^{11} \mathbb{1}$, Isaac López-Laval ${ }^{12} \oplus$, \\ Sergej M. Ostojic ${ }^{13}$, Margaret T. Jones ${ }^{14}{ }^{\mathbb{D}}$, Pedro E. Alcaraz ${ }^{2,5}{ }^{\oplus}$, Xavi Schelling ${ }^{15}$, Anne Delextrat ${ }^{2,16}{ }^{(D}$, \\ Meeta Singh ${ }^{17}$, Jonathan Charest ${ }^{18,19}$, Tomás T. Freitas ${ }^{5,20}{ }^{(1)}$, Lorena Torres Ronda ${ }^{21}$, Adam Petway ${ }^{22}$, \\ Daniel Medina ${ }^{22}$, Antonio Tramullas ${ }^{23}$, Juan Mielgo-Ayuso ${ }^{24}{ }^{\mathbb{D}}$, Nicolas Terrados ${ }^{25}$ and Chris McLellan ${ }^{3}$
}

check for updates

Citation: Calleja-González, J.; Bird, S.P.; Huyghe, T.; Jukic, I.; Cuzzolin, F.; Cos, F.; Marqués-Jiménez, D.; Milanovic, L.; Sampaio, J.;

López-Laval, I.; et al. The Recovery Umbrella in the World of Elite Sport: Do Not Forget the Coaching and Performance Staff. Sports 2021, 9, 169. https://doi.org/10.3390/sports9120169

Academic Editor: Nicolas Babault

Received: 18 November 2021 Accepted: 10 December 2021 Published: 17 December 2021

Publisher's Note: MDPI stays neutral with regard to jurisdictional claims in published maps and institutional affiliations.

Copyright: (c) 2021 by the authors. Licensee MDPI, Basel, Switzerland. This article is an open access article distributed under the terms and conditions of the Creative Commons Attribution (CC BY) license (https:// creativecommons.org/licenses/by/ $4.0 /)$.
1 Department of Physical Education and Sports, Faculty of Education and Sport, University of the Basque Country, (UPV/EHU), 01007 Vitoria-Gasteiz, Spain

2 Strength and Conditioning Society, 00118 Rome, Italy; palcaraz@ucam.edu (P.E.A.); adelextrat@brookes.ac.uk (A.D.)

3 School of Health and Wellbeing, University of Southern Queensland, Ipswich, QLD 4305, Australia; stephen.bird@usq.edu.au (S.P.B.); chris.mcmlellan@usq.edu.au (C.M.)

4 Basketball New Zealand, Wellington 6141, New Zealand

5 UCAM Research Center for High Performance Sport, University of Murcia (UCAM), 30107 Murcia, Spain; thomashuyghe@hotmail.com (T.H.); tfreitas@ucam.edu (T.T.F.)

6 School of Kinesiology, University of Zagreb, 10000 Zagreb, Croatia; ijukic@kif.hr

7 Technogym SpA, 47521 Cesena, Italy; fcuzzolin@technogym.com

8 National Institute of Physical Education (INEFC), University of Barcelona, 08038 Barcelona, Spain; cosfrancesc@gmail.com

9 Faculty of Education, University of Valladolid, 42004 Soria, Spain; diego.marques@uva.es

10 Faculty of Kinesiology, University of Zagreb, 10110 Zagreb, Croatia; luka.milanovic@kif.hr

11 Creative Lab Research Community, Research Center in Sports Sciences, Health Sciences and Human Development, CIDESD, University of Trás-os-Montes and Alto Douro, 5001-801 Vila Real, Portugal; ajaime@utad.pt

12 Department of Physiatry and Nursing, Faculty of Health and Sport Science, University of Zaragoza, 50009 Huesca, Spain; isaac@unizar.es

13 Faculty of Sport and Physical Education, University of Novi Sad, 21102 Novi Sad, Serbia; sergej@panet.co.yu

14 School of Kinesiology, George Mason University, Manassas, VA 20110, USA; mjones15@gmu.edu

15 Institute for Health and Sport, Victoria University, Melbourne, VIC 8001, Australia; xschelling@gmail.com

16 Department of Sport, Health Sciences and Social Work, Oxford Brookes University, Oxford OX3 0BP, UK

17 Performance Sleep Medicine, Detroit, MI 48202, USA; meeta@meetasinghmd.com

18 Department of Kinesiology, University of Calgary, Calgary, AB T2N 1N4, Canada; jcharest@centreforsleep.com

19 Centre for Sleep \& Human Performance, Calgary, AB T2X 3V4, Canada

20 NAR-Nucleus of High Performance in Sport, São Paulo 04753-060, Brazil

21 Spanish Basketball Federation, 28036 Madrid, Spain; lorenatorres07@yahoo.es

22 Washington Wizards Athlete Care Department, Washington, DC 20004, USA; adampetway@gmail.com (A.P.); dmedina@monumentalsports.com (D.M.)

23 Aspire Center for Excellence, Doha 29222, Qatar; drtramullas@telefonica.net

24 Department of Health Sciences, Faculty of Health Sciences, University of Burgos, 09001 Burgos, Spain; juankaya@msn.com

25 Unidad Regional de Medicina Deportiva, Avilés and Instituto de Investigación Sanitaria del Principado de Asturias (ISPA), 33401 Oviedo, Spain; nterrados@ayto-aviles.es

* Correspondence: julio.calleja.gonzalez@gmail.com 
Therefore, the aim of this opinion was to (1) develop an educational recovery resource for team staff members, (2) identify organizational task-specific fatigue indicators and barriers to recovery and self-care in team staff members, and (3) present recovery implementation strategies to assist team staff members in meeting their organizational functions. It is essential that we do not forget the coaching and performance staff in the recovery process.

Keywords: recovery; performance; staff; fatigue

\section{Introduction}

Recovery is a trending topic in the field of sports science [1], and even more so in the world of elite sport. This is evidenced by the significant increase [1,2] in scientific publications during the last 10 years as teams look to find a competitive edge during competitions. Different protocols describe specific recovery methodologies that can be employed in order to achieve more efficient recovery processes, these include (1) recovery strategies [2,3] — foam roll [4,5], massage [6], compression garments [7,8], stretching [9], nutrition [10], active recovery [11], sleep [12], water immersion [13], (2) combinations of recovery strategies [14,15], (3) sport-specific recovery characteristics-soccer [16,17], basketball [18,19], volleyball [20], rugby [21], and combat sports [22], and (4) emerging recovery strategies [23]. Additionally, factors, such as recovery time-periods-post-match $[16,17]$ and during congested schedules [24], have also been investigated, with emerging literature examining recovery specific to female athletes [25] and youth athletes [26,27]. However, it is notable that the recovery of coaching and performance staff in elite sports seems to have been forgotten. This opinion delineates the elite sports organizational structure and specific performance-fatigue characteristics of team staff members and key recovery considerations.

\section{Recovery Domains}

Recovery is a complex, multifactorial issue. Collectively, the scientific literature reports that the primary aim of recovery methods is to accelerate the biological recovery process in shorter time periods [16]. Bird [3] described four essential recovery domains, these being neural, muscular, substrate, and psychological (Table 1). Additionally, selfperception of perceived recovery is also an important consideration, which may affect the balance between happiness and wellness in elite sports athletes [28], especially during periods of congested travel and competition. Key observations from research on recovery in team sports highlight the fatiguing effect of traveling $[29,30]$ in addition to training and competing [31]. As a result, new approaches and practical applications of recovery strategies have been discussed to optimize travel and minimize its negative effects on health and performance in team sports athletes [32], with little mention of coaching and performance staff members [33].

Table 1. Essential recovery domains.

\begin{tabular}{llll}
\hline Domain & Recovery Strategy Examples & Evidence & Reference \\
\hline Neural & Compression, Massage & $\uparrow \leftrightarrow$ & {$[6-8]$} \\
Muscular & Hydrotherapy, Contrast water therapy, Massage & $\uparrow \uparrow \leftrightarrow$ & {$[13,14]$} \\
Substrate & Nutrition, Hydration & $\uparrow \uparrow$ & {$[2,10]$} \\
Psychological & Sleep, Mindfulness & $\uparrow \uparrow$ & {$[34-36]$} \\
Sociological & Social interactions (family-friends) & $\uparrow$ & {$[37]$} \\
\hline
\end{tabular}

Level of evidence: Strong $=\uparrow$, Inconsistent $=\leftrightarrow$.

However, to maximize physical and psychological function and subsequently, performance in elite team sports (National teams, Division I teams), the presence of qualified personnel who are on the front-line helping players, such as the team staff members, is essential [38]. Nowadays, in the lucrative and competitive world of professional team 
sports, team staff members are made of different profiles [39], which in turn, are organized into two pillars: Team sport coaches and Performance staff. Figure 1 displays an overview of a professional team-sport organizational dynamics structure of team staff members' roles within elite sports settings. This is a crucial consideration when managing the health and wellbeing of elite coaches and performance staff. This extends the Integrated Performance Health Management and Coaching Model proposed by Dijkstra et al. [40], providing clarity and perspective related to the complex environment of team staff members in elite sports.

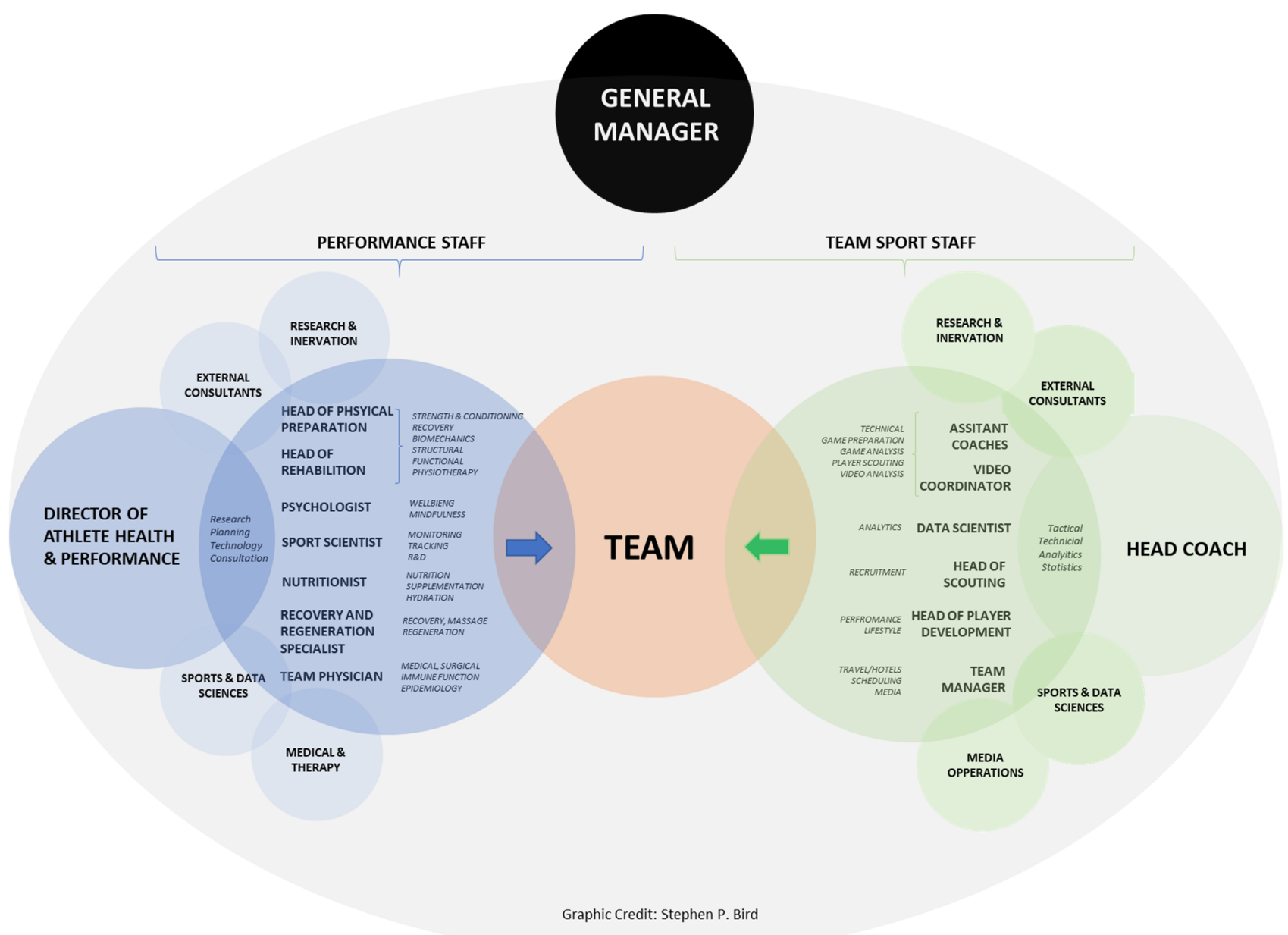

Figure 1. Schematic of professional team organizational structure dynamics comprised of the Team Sport Staff (green shade) and Performance Staff (blue shade) centered around the Team (orange shade). Within the organizational structure, each staff provides expertise related to specific key performance indicators. Modified from Connolly [41].

\section{Fatigue in Team Staff Members}

There now exists a list of characteristics differentiating expert and competent coaches [42,43], and these attributes can aid in the selection, evaluation, and professional development. Coaches, like athletes, strive to gain employment at an elite level in high-performance sports. However, Kellmann and colleagues [44] highlight that coaching in elite sports is "capricious and dependent upon winning performances and players' satisfaction" ( $p$. 240). The high-performance sports setting is considered an uncontrollable, unpredictable, and complex environment, with coaches subjected to a multitude of internal and external stressors (i.e., athlete performance, expectations, external scrutiny), that often result in recovery-stress imbalance $[44,45]$. This may result in coaches presenting with symptoms associated with psycho-socio physiological fatigue burden [46-49], which can be exacerbated by dehydration, hormonal disturbances, caloric restrictions, or sleep disturbances. 
Regarding team staff members (sports coaches and performance staff), common daily tasks and responsibilities, media engagements, study and work commitments, repetitive tasks, over-analysis, thinking about the sport in question, and environmental instability can serve as potential causes of mental fatigue-related issues, with experience and personality as factors of individual susceptibility [50]. Russell and colleagues [50] reported that such issues may lead to more severe consequences, such as disengagement, decreased motivation and enthusiasm, increased displays of emotion and withdrawal, changes in concentration, decreased discipline and attention to detail, as previously described in reports from the elite sporting environment, which can have a negative impact on the team staff performance if left untreated or underappreciated.

In addition, this is an assumption as a lot of team staff members are ex-athletes and remain quite physically active. Additionally, the stress that competition can cause to coaching and performance personnel should be another fundamental factor to consider elevated levels of subjective stress, alpha-amylase activity, and unpleasant emotions suggest that educational programs may be useful for some coaches to manage psychological states during competition [51]. A situation of combined stress for an important championship was found to decrease the level of secretory IgA-mediated immune protection at the mucosal surface, with greater changes observed in the athletes [52]. As such, strategies to minimize the physiological impact are warranted.

\section{Recovery Considerations for Team Staff Members}

The job description of the team staff members can be extensive and demanding [53]. To better cope with the challenges of daily work and with various fatigue sources, support team staff members need to maintain a high level of health, fitness, and mental wellbeing. Fitness, in addition to health protection, plays an important role in mental wellbeing and adaptation to demanding cognitive and social situations [54]. Like athletes, if team staff members possess high levels of health, fitness, and mental wellbeing, they may tolerate fatigue better-that is to say, when in fatigued situations (physical and/or psychological), their capacity to maintain performance will be less affected. Hence, and given the key role of team staff members' work outputs, and potential impact on the team's overall performance [44], to that extent, the importance of recovery, especially related to cognitive and psychological fatigue, can contribute to optimizing performance outcomes.

The development of educational recovery resources for team staff members may also help address the identified barriers and improve knowledge [3,55,56]. For example, while team staff members have adequate overall sleep hygiene knowledge [57], some specific areas (e.g., sleep-wake cycle behaviors) warrant further education. Sleep hygiene education is reported to result in positive changes in sleep behavior [34,35]. However, changes in sleep from education in an acute setting may not be sustained following the initial intervention. The progress of instructive sleep resources for team staff members to implement with athletes may help address the identified barriers and improve sleep knowledge. This may be linked to the negative influence of travel, and possible time zone changes [30,32] is another area where education would be beneficial. Empirical findings and practical recommendations are highlighted on sleep, nutrition, recovery, and scheduling strategies to alleviate the negative effects of air travel on health and performance [30,31,58]. Additionally, it would be helpful to have access to a sport psychologist role to address the psychological needs of team staff members to better prepare them for the heavy and indisputable fatigue accumulation during the season [59].

It has been previously demonstrated in athletes that planned disruptions, such as location, competition simulation, punishments and rewards, physical strain, stronger competition, distractions, unfairness or restrictions, can be used to familiarize athletes with pressure, create awareness, develop personal resources, and promote team processes [60]. This is based on the 'Challenge model of resilience' presented by Fergus and Zimmerman [61], which suggests that exposure to some adversity can strengthen resistance against future adversity. Consequently, this may also be a consideration to prepare support staff 
members to deal with pressure under high-stakes circumstances, which they may face frequently. The response to accumulative stress challenges may be exhibited as increased postural tension. Recently, diaphragmatic breathing has been reported to reduce physiological and psychological stress [62]. The potential beneficial effects of diaphragmatic breathing and neural stretching techniques (nerve-directed stretching) [63] may reduce postural tension.

The majority of coaches, regardless of their culture, seem to face difficulties in obtaining professional work and family life (work/family balance), although other coaches indicate that their family life serves as a protection for engagement in a passionate profession [64]. Nevertheless, these potentially conflicting social spheres of work/family balance require special consideration because they have a direct impact on their work performance and potentially on their athletes. Interpersonal relationships within the coaching and the performance teams may also determine the level of stress, fatigue, burnout, and need for recovery. In fact, it is known that quality relationships within a performance department reduce the possibility of injury to athletes [65]. Thus, it is quite certain that the maintenance of a balance between their professional and family commitments and good relations within and between the coaching and performance teams will generate a better mental and physical condition of the staff members of these teams. Strategies such as mindfulness may play a significant role in assisting coaches by strengthening attention and resilience [66]. Birrer and colleagues [36] outline two dimensions of mindfulness that may transfer to work/family balance, these being (1) self-regulation of attention, and (2) the attitude of openness to experience, while a sense of wellness can be promoted through mediation and creative visualization [67]. Furthermore, nonwork outlets are important contributors to fulfill work-life balance [37].

Considering job insecurity as an inherent stressor for coaches, it should be acknowledged and targeted within coaches' education [68]. Besides moving away from coaching at the elite level, they unanimously mentioned that they changed their approach to coaching to make recovery possible [33]. Therefore, some of the possible means of target recovery that team staff members could use are presented in Table 2. This is an essential consideration given that recovery, as well as social support, might be important in managing stressors associated in the challenging high-performance work environments of full-time coaches. Collectively, this could have a considerable impact on immune health [69]. 
Table 2. Team staff members' coaching domains, potential fatigue consequences, health risk, and recovery focus areas.

\begin{tabular}{|c|c|c|c|c|c|c|c|c|}
\hline Domain & Title & Primary Role & Game Travel & Potential Fatigue & Health Risk & Recovery Focus & Recovery Strategies & Reference \\
\hline Performance Coaching & $\begin{array}{l}\text { Head Coach } \\
\text { Assistant Coach } \\
\text { Head of Player Development } \\
\text { Head of Scouting }\end{array}$ & $\begin{array}{l}\text { Planning, preparation, coaching } \\
\text { Logistical support for head coach } \\
\text { Develop pathway to professional } \\
\text { Athlete identification, recruitment }\end{array}$ & 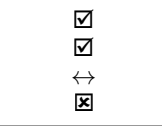 & $\begin{array}{l}\text { Travel } \\
\text { Psychological/Emotional } \\
\text { Asthenopia (eyestrain) } \\
\text { Postural fatigue }\end{array}$ & $\begin{array}{l}\text { Sleep disorders } \\
\text { Emotional exhaustion } \\
\text { Social isolation } \\
\text { Back health }\end{array}$ & $\begin{array}{l}\text { 1.Immune health } \\
\text { 2.Postural re-sets } \\
\text { 3.Sleep hygiene } \\
\text { 4.Mindfulness }\end{array}$ & $\begin{array}{l}\text { Immune Health } \\
\text { Probiotics } \\
\text { Vitamin C } \\
\text { Vitamin D }\end{array}$ & {$[69,70]$} \\
\hline $\begin{array}{l}\text { Sports and Data } \\
\text { Sciences }\end{array}$ & $\begin{array}{l}\text { Video coordinator } \\
\text { Performance analyst } \\
\text { Sport Scientist } \\
\text { Biostatistician }\end{array}$ & $\begin{array}{l}\text { Create/Edit/log film clips } \\
\text { Performance analytics } \\
\text { Research innervation } \\
\text { Statistical analysis }\end{array}$ & $\begin{array}{l}\square \\
\leftrightarrow \\
\leftrightarrow \\
\leftrightarrow\end{array}$ & $\begin{array}{l}\text { Cognitive } \\
\text { Asthenopia (eyestrain) } \\
\text { Postural fatigue }\end{array}$ & $\begin{array}{l}\text { Eye health (CVS) } \\
\text { Sleep disorders } \\
\text { Carpal tunnel } \\
\text { Back health }\end{array}$ & $\begin{array}{l}\text { 1.Postural re-sets } \\
\text { 2.Sleep hygiene } \\
\text { 3.Mindfulness }\end{array}$ & $\begin{array}{l}\text { Sleep Hygiene } \\
\text { Maintain a regular schedule } \\
\text { Minimize electronic use } \\
\text { Room temperature }\left(18-21^{\circ}\right) \\
\text { Dark (blackout curtains) }\end{array}$ & {$[34,35,57]$} \\
\hline Medical and Therapy & $\begin{array}{l}\text { Team Physician } \\
\text { Athletic Trainer } \\
\text { Massage Physiotherapist } \\
\text { Sport Psychologist } \\
\text { Osteopath }\end{array}$ & $\begin{array}{l}\text { Medical diagnosing and treatment } \\
\text { Athlete taping, injury prevention } \\
\text { Soft tissue treatment } \\
\text { Psychological interventions } \\
\text { Musculoskeletal manipulation }\end{array}$ & 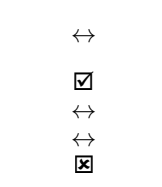 & $\begin{array}{l}\text { Travel } \\
\text { Cognitive } \\
\text { Physical }\end{array}$ & $\begin{array}{l}\text { Psychological } \\
\text { exhaustion } \\
\text { Sleep disorders }\end{array}$ & $\begin{array}{l}\text { 1.Sleep hygiene } \\
\text { 2.Mindfulness }\end{array}$ & $\begin{array}{l}\text { Mindfulness } \\
\text { Relaxation techniques } \\
\text { Creative visualization } \\
\text { Meditation } \\
\text { Desensitization } \\
\text { Journaling thoughts }\end{array}$ & {$[36,67]$} \\
\hline
\end{tabular}

Abbreviations: Yes $=\square ; \mathrm{No}=\bigotimes ;$ Sometimes $=\leftrightarrow ;$ Computer vision syndrome $=\mathrm{CVS}$ 


\section{Conclusions}

The health, wellbeing, and performance of team staff members is of utmost importance in elite sport high-performance organizations, given that their work outputs and capabilities are essential to successful team operation. For these functions to be optimized, recovery strategies targeting the identified fatigue consequences of team staff members should be implemented based on individual fatigue indicators. To assist with the implementation of recovery strategies for coaching and performance staff, integration requires education, individualization, and personalization [3].

Finally, we highlighted that the concepts and practical suggestions related to the recovery of team staff members working in elite sport settings presented in this paper may transfer to staff working within sports schools, sports academies, and/or government sports institutions. Successful implementation will assist team staff members in meeting their organizational functions. Therefore, it is essential that we do not forget the coaching and performance staff in the recovery process.

Author Contributions: S.P.B. designed the graphic. All authors have contributed expert opinion to the manuscript. All authors have read and agreed to the published version of the manuscript.

Funding: This research received no external funding.

Institutional Review Board Statement: Not applicable.

Informed Consent Statement: Not applicable.

Data Availability Statement: No data presented in this study.

Acknowledgments: No acknowledgements are to be made for assistance in the preparation of this article.

Conflicts of Interest: The authors declare no conflict of interest.

\section{References}

1. Kellmann, M.; Bertollo, M.; Bosquet, L.; Brink, M.; Coutts, A.J.; Duffield, R.; Erlacher, D.; Halson, S.L.; Hecksteden, A.; Heidari, J.; et al. Recovery and performance in sport: Consensus statement. Int. J. Sports Physiol. Perform. 2018, 13, 240-245. [CrossRef] [PubMed]

2. Terrados, N.; Mielgo-Ayuso, J.; Delextrat, A.; Ostojic, S.M.; Calleja-Gonzalez, J. Dietetic-nutritional, physical and physiological recovery methods post-competition in team sports. J. Sports Med. Phys. Fit. 2019, 59, 415-428. [CrossRef]

3. Bird, S.P. Implementation of recovery strategies: 100-point weekly recovery checklist. Int. J. Athl. Ther. Train. 2011, 16, 16-19.

4. Cheatham, S.W.; Kolber, M.J.; Cain, M.; Lee, M. The effects of self-myofascial release using a foam roll or roller massager on joint range of motion, muscle recovery, and performance: A systematic review. Int. J. Sports Phys. Ther. 2015, 10, 827-838.

5. Liebenson, C. Postural exercises on the foam roll. J. Bodyw. Mov. Ther. 2010, 14, 203-205. [CrossRef]

6. Best, T.M.; Crawford, S.K. Massage and postexercise recovery: The science is emerging. Br. J. Sports Med. 2017, 51, 1386-1387. [CrossRef]

7. Brown, F.; Gissane, C.; Howatson, G.; van Someren, K.; Pedlar, C.; Hill, J. Compression garments and recovery from exercise: A meta-analysis. Sports Med. 2017, 47, 2245-2267. [CrossRef]

8. Marqués-Jiménez, D.; Calleja-González, J.; Arratibel, I.; Delextrat, A.; Terrados, N. Are compression garments effective for the recovery of exercise-induced muscle damage? A systematic review with meta-analysis. Physiol. Behav. 2016, 153, 133-148. [CrossRef] [PubMed]

9. Pooley, S.; Spendiff, O.; Allen, M.; Moir, H.J. Static stretching does not enhance recovery in elite youth soccer players. BMJ Open Sport Exerc. Med. 2017, 3, e000202. [CrossRef]

10. Ranchordas, M.K.; Dawson, J.T.; Russell, M. Practical nutritional recovery strategies for elite soccer players when limited time separates repeated matches. J. Int. Soc. Sports Nutr. 2017, 14, 35. [CrossRef]

11. Mika, A.; Oleksy, Ł.; Kielnar, R.; Wodka-Natkaniec, E.; Twardowska, M.; Kamiński, K.; Małek, Z. Comparison of two different modes of active recovery on muscles performance after fatiguing exercise in mountain canoeist and football players. PLoS ONE 2016, 11, e0164216. [CrossRef] [PubMed]

12. Kölling, S.; Venter, R.; Duffield, R.; Erlacher, D.; Halson, S.L. Sleep-related issues for recovery and performance in athletes. Int. J. Sports Physiol. Perform. 2019, 14, 144-148. [CrossRef] [PubMed]

13. Ahokas, E.K.; Ihalainen, J.K.; Kyröläinen, H.; Mero, A.A. Effects of water immersion methods on postexercise recovery of physical and mental performance. J. Strength Cond. Res. 2019, 33, 1488-1495. [CrossRef] [PubMed] 
14. Delextrat, A.; Calleja-González, J.; Hippocrate, A.; Clarke, N.D. Effects of sports massage and intermittent cold-water immersion on recovery from matches by basketball players. J. Sports Sci. 2013, 31, 11-19. [CrossRef]

15. Pooley, S.; Spendiff, O.; Allen, M.; Moir, H.A.-O. Comparative efficacy of active recovery and cold water immersion as post-match recovery interventions in elite youth soccer. J. Sports Sci. 2020, 38, 1423-1431. [CrossRef] [PubMed]

16. Nédélec, M.; McCall, A.; Carling, C.; Legall, F.; Berthoin, S.; Dupont, G. Recovery in soccer: Part I-Post-match fatigue and time course of recovery. Sports Med. 2012, 42, 997-1015.

17. Nédélec, M.; McCall, A.; Carling, C.; Legall, F.; Berthoin, S.; Dupont, G. Recovery in Soccer: Part II-Recovery strategies. Sports Med. 2013, 43, 9-22. [CrossRef]

18. Calleja-González, J.; Terrados, N.; Mielgo-Ayuso, J.; Delextrat, A.; Jukic, I.; Vaquera, A.; Torres, L.; Schelling, X.; Stojanovic, M.; Ostojic, S.M. Evidence-based post-exercise recovery strategies in basketball. Physician Sportsmed. 2016, 44, 74-78. [CrossRef]

19. Huyghe, T.; Calleja-Gonzalez, J.; Terrados, N. Post-exercise recovery strategies in basketball: Practical applications based on scientific evidence. In Basketball Sports Medicine and Science; Laver, L., Kocaoglu, B., Cole, B., Arundale, A.J.H., Bytomski, J., Amendola, A., Eds.; Springer: Berlin/Heidelberg, Germany, 2020.

20. Calleja-Gonzalez, J.; Mielgo-Ayuso, J.; Sanchez-Ureña, B.; Ostojic, S.M.; Terrados, N. Recovery in volleyball. J. Sports Med. Phys. Fitness 2019, 59, 982-993. [CrossRef] [PubMed]

21. Calleja-González, J.; Mielgo-Ayuso, J.; Ostojic, S.M.; Jones, M.T.; Marques-Jiménez, D.; Caparros, T.; Terrados, N. Evidence-based post-exercise recovery strategies in rugby: A narrative review. Physician Sportsmed. 2019, 47, 137-147. [CrossRef]

22. Lopez-Laval, I.; Mielgo-Ayuso, J.; Terrados, N.; Calleja-Gonzalez, J. Evidence-based post exercise recovery in combat sports: A narrative review. J. Sports Med. Phys. Fit. 2021, 61, 386-400. [CrossRef]

23. Thorpe, R.T. Post-exercise recovery: Cooling and heating, a periodized approach. Front. Sports Act. Living 2021, 3, 236. [CrossRef] [PubMed]

24. Howle, K.; Waterson, A.; Duffield, R. Recovery profiles following single and multiple matches per week in professional football. Eur. J. Sport Sci. 2019, 19, 1303-1311. [CrossRef]

25. Horgan, B.G.; Drew, M.K.; Halson, S.L.; Piromalli, L.E.; Drinkwater, E.J.; Chapman, D.W.; Haff, G.G. Impaired recovery is associated with increased injury and illness: A retrospective study of 536 female netball athletes. Scand. J. Med. Sci. Sports 2021, 31, 691-701. [CrossRef] [PubMed]

26. McFarland, M.; Bird, S.P. A wellness monitoring tool for youth athletes. J. Aust. Strength Cond. 2014, 22, 22-26.

27. Sawczuk, T.; Jones, B.; Scantlebury, S.; Till, K. Relationships between training load, sleep duration, and daily well-being and recovery measures in youth athletes. Pediatric Exerc. Sci. 2018, 30, 345-352. [CrossRef]

28. Calleja-González, J.; Terrados, N.; Martín-Acero, R.; Lago-Peñas, C.; Jukic, I.; Mielgo-Ayuso, J.; Marqués-Jiménez, D.; Delextrat, A.; Ostojic, S. Happiness vs. Wellness during the recovery process in high performance sport. Front. Physiol. 2018, 9, 1598. [CrossRef]

29. Calleja-Gonzalez, J.; Marques-Jimenez, D.; Jones, M.; Huyghe, T.; Navarro, F.; Delextrat, A.; Jukic, I.; Ostojic, S.M.; Sampaio, J.E.; Schelling, X.; et al. What are we doing wrong when athletes report higher levels of fatigue from traveling than from training or competition? Front. Psychol. 2020, 11, 194. [CrossRef] [PubMed]

30. Huyghe, T.; Scanlan, A.T.; Dalbo, V.J.; Calleja-González, J. The negative influence of air travel on health and performance in the National Basketball Association: A narrative review. Sports 2018, 6, 89. [CrossRef]

31. Singh, M.; Bird, S.P.; Charest, J.; Huyghe, T.; Calleja-Gonzalez, J. Urgent wake up call for the National Basketball Association. J. Clin. Sleep Med. 2021, 17, 243-248. [CrossRef]

32. Samuels, C.H. Jet lag and travel fatigue: A comprehensive management plan for sport medicine physicians and high-performance support teams. Clin. J. Sport Med. 2012, 22, 268-273. [CrossRef]

33. Hassmén, P.; Kenttä, G.; Hjälm, S.; Lundkvist, E.; Gustafsson, H. Burnout symptoms and recovery processes in eight elite soccer coaches over 10 years. Int. J. Sports Sci. Coach. 2019, 14, 431-443. [CrossRef]

34. O'Donnell, S.; Driller, M.W. Sleep-hygiene education improves sleep indices in elite female athletes. Int. J. Exerc. Sci. 2017, 10, 522-530. [PubMed]

35. Caia, J.; Scott, T.J.; Halson, S.L.; Kelly, V.G. The influence of sleep hygiene education on sleep in professional rugby league athletes. Sleep Health 2018, 4, 364-368. [CrossRef]

36. Birrer, D.; Röthlin, P.; Morgan, G. Mindfulness to enhance athletic performance: Theoretical considerations and possible impact mechanisms. Mindfulness 2012, 3, 235-246. [CrossRef]

37. Mazerolle, S.M.; Goodman, A. Fulfillment of work-life balance from the organizational perspective: A case study. J. Athl. Train. 2013, 48, 668-677. [CrossRef]

38. Macquet, A.C.; Ferrand, C.; Stanton, N.A. Divide and rule: A qualitative analysis of the debriefing process in elite team sports. Appl. Ergon. 2015, 51, 30-38. [CrossRef] [PubMed]

39. Casalsa, M.; Nielsend, R.O. Who and what can contribute to improve the statistical thinking in sports injury research? A humorous analogy between basketball and members of the multidisciplinary research team. Apunt. Sports Med. 2019, 54, 81-84. [CrossRef]

40. Dijkstra, H.P.; Pollock, N.; Chakraverty, R.; Alonso, J.M. Managing the health of the elite athlete: A new integrated performance health management and coaching model. Br. J. Sports Med. 2014, 48, 523-531. [CrossRef] [PubMed]

41. Connolly, F. Professional Team Organizational Dynamics. In High Performance Teams Series; Fergus Connolly; 2019. Available online: https: / / fergusconnolly.com/sport/\#sports (accessed on 12 June 2019). 
42. Chamari, K. The crucial role of elite athletes and expert coaches with academic profiles in developing sound sport science. Int. J. Sports Physiol. Perform. 2019, 14, 413. [CrossRef]

43. LaPlaca, D.A.; Schempp, P.G. The characteristics differentiating expert and competent strength and conditioning coaches. Res. Q. Exerc. Sport 2020, 91, 488-499. [CrossRef]

44. Kellmann, M.; Altfeld, S.; Mallett, C.J. Recovery-stress imbalance in Australian Football League coaches: A pilot longitudinal study. Int. J. Sport Exerc. Psychol. 2016, 14, 240-249. [CrossRef]

45. Carson, F.; Malakellis, M.; Walsh, J.; Main, L.C.; Kremer, P. Examining the mental well-being of Australian sport coaches. Int. J. Environ. Res. Public Health 2019, 16, 4601. [CrossRef]

46. Schaffran, P.; Altfeld, S.; M, K. A review of correlates, measurement and intervention. Dtsch. Z. Sportmed. 2016, 67, 121-126.

47. Raedeke, T.D.; Granzyk, T.L.; Warren, A. Why coaches experience burnout: A commitment perspective. J. Sport Exerc. Psychol. 2000, 22, 85-105. [CrossRef]

48. Altfeld, S.; Mallett, C.J.; Kellmann, M. Coaches' burnout, stress, and recovery over a season: A longitudinal study. Int. Sport Coach. J. 2015, 2, 137-151. [CrossRef]

49. Lock, A.M.; Bonetti, D.L.; Campbell, A.D.K. The psychological and physiological health effects of fatigue. Occup. Med. 2018, 68, 502-511. [CrossRef]

50. Russell, S.; Jenkins, D.; Rynne, S.; Halson, S.L.; Kelly, V. What is mental fatigue in elite sport? Perceptions from athletes and staff. Eur. J. Sport Sci. 2019, 19, 1367-1376. [CrossRef]

51. Hudson, J.; Davison, G.; Robinson, P. Psychophysiological and stress responses to competition in team sport coaches: An exploratory study. Scand. J. Med. Sci. Sports 2013, 23, e279-e285. [CrossRef] [PubMed]

52. Moreira, A.; Arsati, F.; Cury, P.R.; Franciscon, C.; Simoes, A.C.; de Oliveira, P.R.; de Araujo, V.C. The impact of a 17-day training period for an international championship on mucosal immune parameters in top-level basketball players and staff members. Eur. J. Oral Sci. 2008, 116, 431-437. [CrossRef]

53. Jukic, I.; Calleja-González, J.; Cuzzolin, F.; Sampaio, J.; Cos, F.; Milanovic, L.; Krakan, I.; Ostojic, S.; Olmo, J.; Requena, B.; et al. The $360^{\circ}$ performance system in team sports: Is it time to design a "personalized jacket" for team sports players? Sports 2021, 9, 40. [CrossRef] [PubMed]

54. McKinney, J.; Lithwick, D.J.; Morrison, B.N.; Nazzari, H.; Isserow, S.; Heilbron, B.; Krahn, A.D. The health benefits of physical activity and cardiorespiratory fitness. Br. Columbia Med J. 2016, 58, 131-137.

55. Bird, S.P.; Donaghy, M. Recovery Points Checklist. In Basketball New Zealand Infographic Series—BBNZ Resource Library; Basketball New Zealand; 2020. Available online: https://nz.basketball/wp-content/uploads/2020/06/02.-Recovery-Points-Checklist.pdf (accessed on 14 December 2021).

56. Bird, S.P.; Donaghy, M. Recovery Benefits. In Basketball New Zealand Infographic Series—BBNZ Resource Library; Basketball New Zealand; 2020. Available online: https:/ /nz.basketball/wp-content/uploads/2020/06/01.-Recovery-Benefits-BBNZ.pdf (accessed on 14 December 2021).

57. Miles, K.H.; Clark, B.; Fowler, P.M.; Miller, J.; Pumpa, K.L. Sleep practices implemented by team sport coaches and sports science support staff: A potential avenue to improve athlete sleep? J. Sci. Med. Sport 2019, 22, 748-752. [CrossRef]

58. Bird, S.P. Sleep, recovery and athletic performance: A brief review and recommendations. Strength Cond. J. 2013, 35, 43-47. [CrossRef]

59. Cropley, B.; Thelwell, R.; Mallett, C.J.; Dieffenbach, K. EPILOGUE-A commentary and reflection on sport psychology in the discipline of sports coaching. J. Appl. Sport Psychol. 2020, 32, 121-128. [CrossRef]

60. Kegelaers, J.; Wylleman, P.; Oudejans, R.R.D. A coach perspective on the use of planned disruptions in high-performance sports. Sport Exerc. Perform. Psychol. 2020, 9, 29-44. [CrossRef]

61. Fergus, S.; Zimmerman, M.A. Adolescent resilience: A framework for understanding healthy development in the face of risk. Annu. Rev. Public Health 2005, 26, 399-419. [CrossRef] [PubMed]

62. Hopper, S.I.; Murray, S.L.; Ferrara, L.R.; Singleton, J.K. Effectiveness of diaphragmatic breathing for reducing physiological and psychological stress in adults: A quantitative systematic review. JBI Evid. Synth. 2019, 17, 1855-1876. [CrossRef]

63. Andrade, R.J.; Freitas, S.R.; Hug, F.; Sant, G.L.; Lacourpaille, L.; Gross, R.; Quillard, J.-B.; McNair, P.J.; Nordez, A. Chronic effects of muscle and nerve-directed stretching on tissue mechanics. J. Appl. Physiol. 2020, 129, 1011-1023. [CrossRef] [PubMed]

64. Joncheray, H.; Burlot, F.; Julla-Marcy, M. Is the game lost in advance? Being a high-performance coach and preserving family life. Int. J. Sports Sci. Coach. 2019, 14, 453-462. [CrossRef]

65. Ekstrand, J.; Lundqvist, D.; Davison, M.; D'Hooghe, M.; Pensgaard, A.M. Communication quality between the medical team and the head coach/manager is associated with injury burden and player availability in elite football clubs. Br. J. Sports Med. 2019, 53, 304-308. [CrossRef]

66. Jha, A.P.; Rogers, S.L.; Morrison, A.B. Chapter 15-Mindfulness Training in High Stress Professions: Strengthening Attention and Resilience. In Mindfulness-Based Treatment Approaches, 2nd ed.; Baer, R.A., Ed.; Academic Press: San Diego, CA, USA, 2014.

67. Margolin, I.; Pierce, J.; Wiley, A. Wellness through a creative lens: Mediation and visualization. J. Relig. Spiritual. Soc. Work. Soc. Thought 2011, 30, 234-252. [CrossRef]

68. Bentzen, M.; Kenttä, G.; Lemyre, P.-N. Elite football coaches experiences and sensemaking about being fired: An interpretative phenomenological analysis. Int. J. Env. Res. Public Health 2020, 17, 5196. [CrossRef] [PubMed] 
69. Walsh, N.P. Recommendations to maintain immune health in athletes. Eur. J. Sport Sci. 2018, 18, 820-831. [CrossRef] [PubMed]

70. Walsh, N.P. Nutrition and athlete immune health: New perspectives on an old paradigm. Sports Med. 2019, 49, 153-168. [CrossRef] 